Tükiye Tarımsal Araştırmalar Dergisi
dergipark.gov.tr/tutad $\begin{aligned} & \text { Turk J Agric Res } \\ & \text { 2018, 5(2): 131-142 } \\ & \text { ( TÜTAD } \\ & \text { ISSN: 2148-2306 } \\ & \text { e-ISSN: 2528-858X } \\ & \text { doi: 10.19159/tutad.382340 }\end{aligned}$

\title{
Samsun İlinin Newhall Modeline Göre Toprak Sıcaklık ve Nem Rejimlerinin Belirlenmesi
}

\author{
Mümin TURAN ${ }^{1}$, Orhan DENGİZ ${ }^{2}$ İnci DEMIRAĞ TURAN ${ }^{3 *}$ \\ ${ }^{I}$ Meteoroloji Genel Müdürlüğ̈̈, Meteoroloji 10. Bölge Müdürlüğ̈̈, Samsun, TÜRKİYE \\ ${ }^{2}$ Ondokuz Mayıs Üniversitesi, Ziraat Fakültesi, Toprak Bilimi ve Bitki Besleme Bölümü, Samsun, TÜRKIYE \\ ${ }^{3}$ Giresun Üniversitesi, Fen Edebiyat Fakültesi, Coğrafya Bölümü, Giresun, TÜRKIYE
}

\begin{tabular}{l}
\hline \multicolumn{1}{c}{ Geliş Tarihi/Received: $22.01 .2018 \quad$ Kabul Tarihi/Accepted: 21.05 .2018} \\
\hline ORCID ID (Yazar sirasina göre / by author order) \\
(D)orcid.org/0000-0001-9573-694X (D) orcid.org/0000-0002-0458-6016 (iD)orcid.org/0000-0002-5810-6591 \\
"Sorumlu Yazar/Corresponding Author: dmrginci@gmail.com
\end{tabular}

Özet: Bu çalışmanın amacı, farklı coğrafik ve ekolojik özelliklere sahip Samsun ilinde dağılım gösteren toprakların Newhall simülasyon modeli yardımıyla toprak sıcaklık ve nem rejimlerinin belirlenmesidir. Çalışmada uzun yıllar ortalama yağı̧s ve sıcaklık verilerine sahip 6 istasyon (Atakum, Bafra, Çarşamba, Lâdik, Havza ve Vezirköprü) verisi hesaba katılmıştır. Ayrıca ilin iklim sınıflamasını belirlemek amacıyla Erinç ve Thornthwaite iklim sınıflaması kullanılmıştır. Erinç iklim sınıflamasına göre Samsun ilinin doğu kısımları nemli sınıfı içerisinde yer alırken, orta ve batı kesimler yarı nemli sınıfa girmektedir. Thornthwaite iklim sınıflaması dikkate alındığında ise yine doğu kesimler nemli, orta sahil kesimler nemli ve yarı nemli, Bafra ilçesinin yüksek kesimleri ile Vezirköprü yarı kurak az nemli iken, iç kısımlarda yer alan Havza ve Kavak ilçelerinin bir kısmı yarı kurak olarak sınıflandırılmıştır. Newhall modeline göre Samsun ilinin sıcaklık rejimi tüm istasyonlar Mesic olarak sınıflandırılırken; nem rejimi bakımından ise Lâdik, Havza ve Vezirköprü Typic Xeric, Atakum ve Bafra ilçeleri Wet Tempustic, Çarşamba ise Dry Tempudic olarak sınıflandırılmıştır. Ayrıca, Newhall modeli ile elde edilen toprak sıcaklık ve nem dağılım grafikleri sayesinde toprak su yönetim ve kuraklık çalışmalarına önemli altlık verileri oluşturacağı da önerilmektedir.

Anahtar Kelimeler: Toprak nem ve sıcaklık rejimi, Newhall simülasyon modeli, Samsun

\section{Determination of Soil Moisture and Temperature Regimes for Samsun Province According to Newhall Model}

\begin{abstract}
The aim of this research was to determine soil moisture and temperature regimes for soils in Samsun province, which has various geographical and ecological properties, using Newhall simulation model. Data from six stations (Atakum, Bafra, Carșamba, Ladik, Havza, and Vezirköprü) with average rainfall and temperature records for many years participated in the study. Also, Erinç, and Thorwhite climate classification systems were used in order to determine climate classification of the province. According to Erinç climate classification, the eastern parts of Samsun are located in the humid class while the middle and western sections are in semi-humid class. When the Thornthwaite climate classification is taken into account, the eastern sections are found humid and the middle coast sections are fund humid and semi-humid. The high sections of the Bafra district and the Vezirköprü are semi-arid and less humid, while some of the Havza and Kavak districts in the inner part are classified as semi-arid. According to Newhall model, soil temperature regime of all Samsun' area was classified as Mesic. In terms of humidity regime, Ladik, Basin, and Vezirköprü are classified as Typic Xeric, Atakum and Bafra districts as Wet Tempustic and Çarşamba as Dry Tempudic. It is also suggested that the soil temperature and moisture distribution plots obtained with the Newhall model will provide important support for soil water management and drought studies.
\end{abstract}

Keywords: Soil temperature and moisture regimes, Newhall simulation model, Samsun province 


\section{Giriș}

Yer kabuğunun üzerinde, kesin sınırı olmayan ve içinde litosfer, atmosfer, hidrosfer ve biyosferin birbirine girişim yaptığ pedosfer denir ve topraklar pedosfere ait canlı varlıklar olarak nitelendirilebilir. Toprak oluşuma bağlı olarak, ekosistemin kurulması yüz yılları alır. Topraklar tarihsel ve evrimsel olarak oluşumları aşağıdan yukarıya doğru işleyen bir süreçte, bulunduğu çevre şartları içerisinde kendilerine özgü karakter kazanırlar. Bu sürecin insan yaşam süresi ile karşılaştırıldığında çok uzun olması, toprak olarak ifade edilen varlığın görülmesini ve algılanılmasını mümkün kılmamaktadır. Fakat oluşum sonrasında üstlenmiş oldukları çok önemli görev ve hizmetler ile karasal ekosistemlerin çok önemli vazgeçilmez yapı taşlarından biri haline gelir.

Toprağın doğal oluşum sürecini değiştirmenin olanaksız olduğu gibi, teknolojik usullerle yapay üretilmesinin de mümkün olmamasının yanı sıra, beklenen faydası ve fonksiyonunu kaybetmesi halinde yerine başka bir kaynağın kullanılması da mümkün değildir. $\mathrm{Bu}$ nedenle toprak konusunda diğer doğal kaynaklara oranla daha hassas olmak gerektiği açıkça görülmektedir. Yapılan araştırmalara göre $2.5 \mathrm{~cm}$ kalınlığındaki bir toprak tabakasının oluşması için 300 ile 1000 yılın geçmesi gerektiği araştırıcılar tarafından belirtilmiştir (Anonim, 1980). İlk kez Dokuçayev ve sonraları Hilgard belli bir ana-materyalden farklı çevre koşulları altında, özellikle değişik iklim ve vejetasyon etkisi ile farklı toprakların oluştuklarını ortaya koymuşlardır (Akalan, 1969; Buol ve ark., 1973). Joffe (1949), aktif ve pasif olmak üzere iki çeşit toprak oluş faktörünü ayırt etmiştir. Pasif toprak oluş faktörlerinin sadece kitlenin kaynağ olarak hizmet gören maddeler ve kitle üzerine etkili olan koşulları simgelediğini, bunların ana-materyal, topografya ve arazinin yaşı olduğunu belirtmiştir. Aktif toprak oluş faktörlerinin ise toprak oluşu için esas maddeleri ve kitle üzerine etkili olan enerjiyi sağlayan araçlar olduğunu; organizmaların, iklimin ve kısmen de hidrosferin bu sınıfa giren toprak oluş faktörlerini simgelediğini belirtmiştir. Toprak yapan olaylar ise Simonson (1959) tarafindan; toprakta birikme olayları, toprak ana maddelerinin transformasyonu, toprakta yer değişimler, horizonlaşmaya engel olan olaylar, topraktan olan kayıplar olarak açıklanmıştır. Toprakların her biri kendine özgü fiziksel, kimyasal, biyolojik ve morfolojik özellikler kazanmasında, farklı ekolojik ortamlar altında meydana gelmesinin yanı sıra belirtilen tüm bu süreçlerin toprak içerisinde gerçekleşmesinde toprak nem ve sıcaklık faktörleri önemli role sahiptirler. Bu bağlamda; toprak iklimi, atmosferik iklimle bir dereceye kadar farklılık göstermekte olup, her ne kadar atmosferik iklimden önemli ölçüde etkilense bile toprağın tamponlama etkisi nedeniyle bu etki hemen kendisini göstermemektedir. Toprak neminin hidrolojik döngüdeki payı oldukça düşük olmasına karşın birçok hidrolojik, biyolojik ve biyokimyasal süreçte önemi oldukça büyüktür (Brady ve Weil, 2000). Özellikle yar1-kurak bölgelerde toprağa düşen yağışın toprakta tutulması toprakta cereyan eden süreçler için son derece önemlidir. Toprak neminin hidrolojik döngüdeki yerini tayin eden tek faktör ise toprak hidrolik özelliklerinin bir fonksiyonu olan toprak suyunun davranışı, diğer bir ifade ile toprak su bütçesidir. Dolayısıyla, toprakta besin elementi alınımı, besin elementlerinin ve kirleticilerin yıkanması gibi süreçlerin tamamı toprak hidrolik özellikleri tarafından kontrol edilir (Erşahin, 2001).

Yeryüzünün değişik yerlerindeki sıcaklık farkları, toprakta meydana gelen kimyasal olayların hızını etkileyerek toprak oluşumunu dolaylı biçimde yönlendirir (Tanju, 1996). Sicaklığın toprak oluşumunda yapmış olduğu en önemli rolünden bir tanesi de evapotranspirasyonun ve etkili yağış miktarının üzerine yapmış olduğu etkidir. Sıcaklık, bir bölgedeki vejetasyon tipi ve miktarı üzerine ve dolayısıyla oluşan humus tipi ve miktarı üzerine etkilidir. Sıcaklık derecesi arttıkça, topraktaki organik madde ve dolayısıyla azot miktarı artan mikroorganizma etkinliği nedeniyle azalmaktadır (Ekberli ve Dengiz, 2016). Bunun tipik örneği tropiklerdeki Laterit topraklardır. Yoğun vejetasyona karşın, mineralizasyonun çok yüksek oluşu toprakta organik maddenin tutunmasını engellemektedir. Bu arada açığa çıkan bazik elementlerin etkisi ile oluşan $\mathrm{pH}$ yükselmesi, $\mathrm{SiO}_{2}$ (Silisyum dioksit) yıkanmasina neden olduğundan, $\mathrm{SiO}_{2} / \mathrm{R}_{2} \mathrm{O}_{3} \quad$ (Silisyum dioksit/ Seskioksit) oranı 2'den azdır. Daha serin bölgelerdeki podzol ve podzolik topraklarda bu durum aksine bir gelişme göstermektedir (Dinç ve ark., 1987). Bazı araştırmalarda ölçülen toprak sıcaklığına bağlı olarak 1sıl parametreleri ve toprak profili boyunca sicaklığın tahmin edilmesi incelenmiştir (Trombotto ve Borzotta, 2009; Ekberli ve Gülser, 2014; Ekberli ve ark., 2015). Toprak yüzeyinde ve aşağı katmanlardaki sıcaklığın günlük ve yıllık değişimi, toprak özellikleri ile birlikte toprakların termal özelliklerine, dolayısıyla ısısal yayınıma önemli düzeyde bağlı olmaktadır (Gao ve ark., 2007; Özgener ve ark., 2013; Ekberli ve Sarılar, 2015; Dengiz ve Ekberli, 2017). Ayrıca, toprak sıcaklığı aynı zamanda morfometrik esaslara dayandırılarak toprakların ölçülebilen ve gözlenebilen karakteristikleri göz önüne alınarak yapilan toprak taksonomisinde (Anonymous, 1999) önemli bir kriter olup, kategorik ayrımlarda özellikle alt ordo, büyük grup ve familya 
düzeylerindeki sınıfların belirlenmesinde önemli bir faktördür.

Karasal ekosistemin önemli bir parçasını oluşturan toprakların gerek pedogenetik süreçleri üzerinde, gerekse de kullanımları ve yönetimlerinde toprak nem ve sıcaklık rejimlerinin önemli payları bulunmaktadır. Fakat, özellikle geniş ve farklılık gösteren alanlarda bu özelliklerin direk ölçümleri; zaman, maliyet ve iş gücü açısından imkansızdır. $\mathrm{Bu}$ nedenle bu özelliklerin doğruya yakın olarak belirlenebilmesinde bazı modeller kullanılabilmektedir. Bu çalışmanın amacı, farklı coğrafik ve ekolojik özelliklere sahip Samsun ilinde dağılım gösteren toprakların Newhall modeli yardımıyla toprak sicaklık ve nem rejimlerinin belirlenmesidir.

\section{Materyal ve Yöntem}

\subsection{Materyal}

Çalışma, Samsun il sınırları içerisinde yer alan, farklı coğrafi özelliklere ve konuma sahip altı ilçenin (Atakum, Bafra, Çarşamba, Havza, Lâdik ve
Vezirköprü) dağılım gösterdiği alanlarda gerçekleştirilmiştir. Samsun ili; Karadeniz sahil şeridinde Yeşilırmak ve Kızılırmak nehirlerinin Karadeniz'e döküldükleri deltalar arasında yer almakta (Şekil 1) ve $9579 \mathrm{~km}^{2}$ 'lik yüz ölçüme

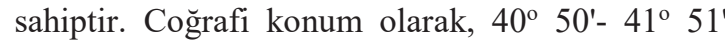
kuzey enlemi ile $37^{\circ} 08^{\prime}$ ve $34^{\circ} 25^{\prime}$ doğu boylamlar arasında yer almaktadır. Yeşilırmak ve Kızılırmak akarsularının deltalarında tarım potansiyeli yüksek Bafra ve Çarşamba Ovaları yer almaktadır (Dengiz ve Sarığlu, 2011). İlin deniz seviyesinden yüksekliği 0-1900 m arasında değişmektedir (Şekil 2).

Samsun ili yeryüzü şekilleri bakımından üç ayrı özellik gösterir. Bunlar; (1) Güneyindeki dağlık kesim, (2) Dağlık kesimle kıyı şeridi arasında kalan yaylalar, (3) Yaylalarla Karadeniz arasında kalan kıyı ovalarıdır.

Samsun ili genellikle 1lıman bir iklime sahiptir. Ancak iklim, sahil şeridi ve iç kesimlerde ayrı özellik gösterir. Sahil şeridinde; yazların sıcak, kışların ılık ve yağışlı geçtiği Karadeniz iklimi

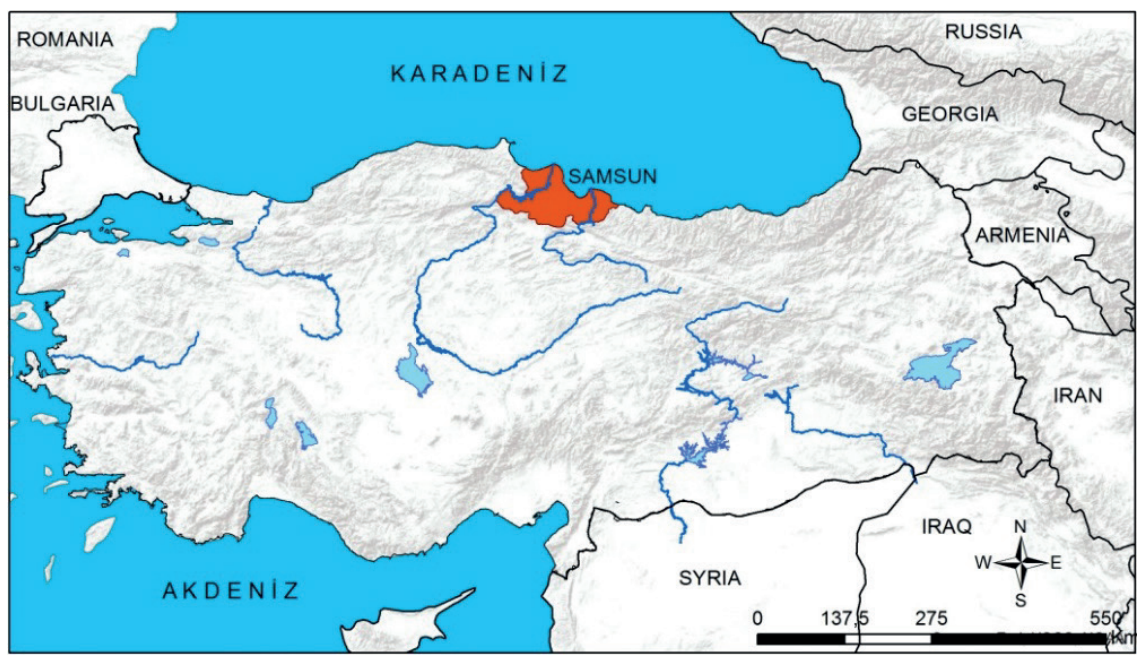

Şekil 1. Çalışma alanının lokasyon haritası

özellikleri görülür. Yıllık ortalama sıcaklık sahil kesimlerde alanı bulunan Bafra, Çarşamba, Terme ve Tekkeköy ilçelerinde $14-15{ }^{\circ} \mathrm{C}$ arasında iken; Havza, Lâdik ve Vezirköprü ilçelerinin yüksek dağ kesimlerinde $5{ }^{\circ} \mathrm{C}$ düzeylerine kadar inmektedir. Dolayısıyla iç kesimler Akdağ ve Canik Dağları'nın etkisinde kalır. $\mathrm{Bu}$ nedenle kışlar soğuk ve kar yağışlı, yazları ise serin geçmektedir. Çok yıllık ortalamalara göre en soğuk ay Mart $\left(7.2^{\circ} \mathrm{C}\right)$, en sıcak ay ise Ağustos $\left(25.4{ }^{\circ} \mathrm{C}\right)$ ayıdır. Şekil 3 incelendiğinde, uzun yıllar ortalama yağış dağılımı yıllık ortalama sıcaklık dağılımı gibi kıyı şeridinde benzerlik göstermemektedir. Samsun'un doğu kıyısında yer alan Çarşamba, Terme ve Tekkeköy ilçesinin bir kısmı 900-1000 mm yağış alırken, batı sahillerinde yer alan Bafra ilçesi 800 ile $900 \mathrm{~mm}$ arasında, orta kesimlerde ise $700 \mathrm{~mm}$ civarında ortalama yağış almaktadır. Kuzey kesimlerde yer alan Vezirköprü ve Havza ilçeleri özellikle Canik Dağları'nın etkisi nedeniyle yağış miktarı 500-600 mm'ye kadar azaldığı görülmektedir.

Çalışmada Atakum (1962-2016), Bafra (19632016), Çarşamba (1966-1992), Havza (1986-1999), Lâdik (1976-1999) ve Vezirköprü (1977-1994) meteorolojik istasyonlarına ait verilerden uzun yıllar ortalama yağış ve sıcaklık verileri kullanılmıştır (Tablo 1). 


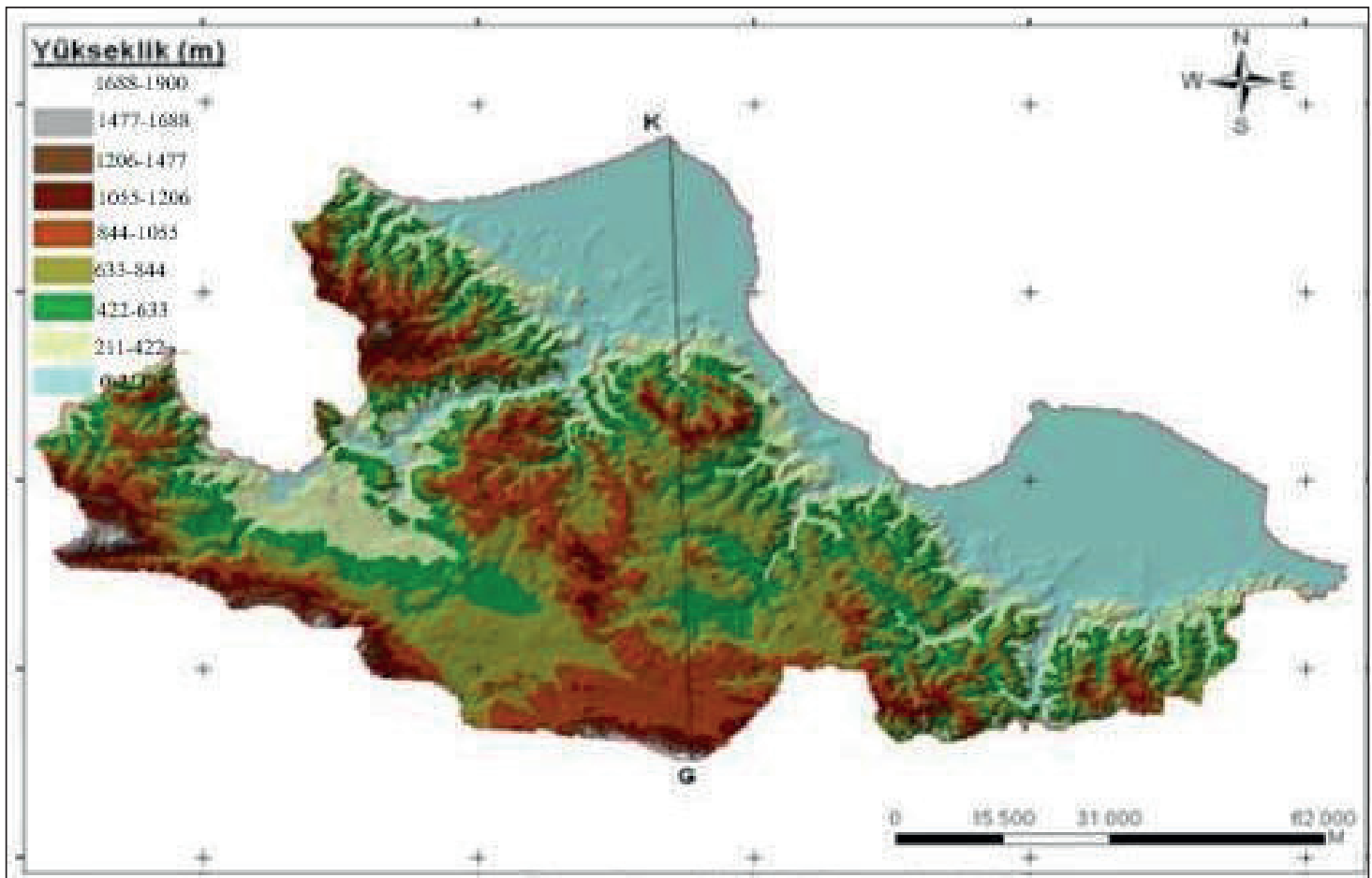

Kuzey-Guney Yönünde Topografik Kesit

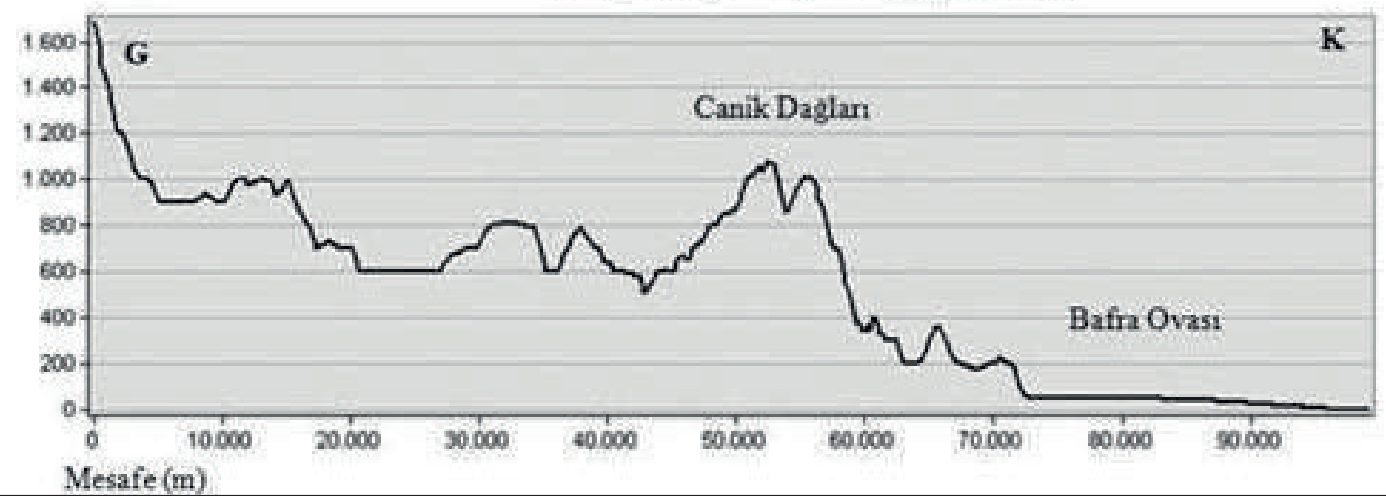

Şekil 2. Samsun ili yükseklik dağılımı ve topografik kesit görünümü
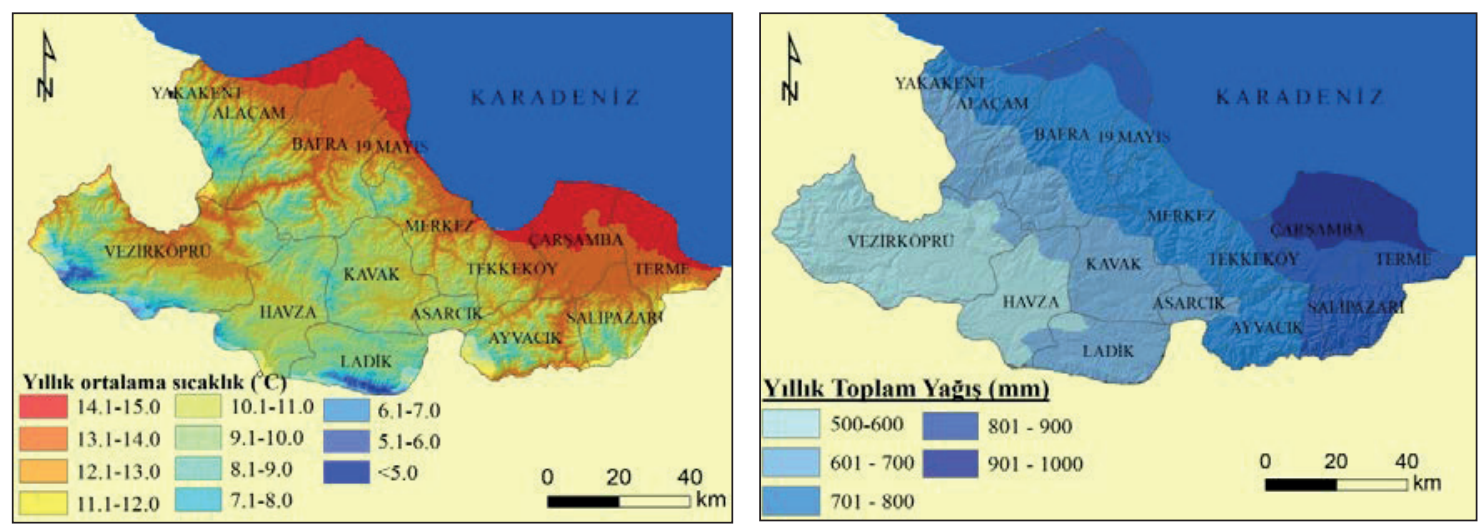

Şekil 3. Samsun iline ait sıcaklık ve yağış dağılım haritaları 
Tablo 1. Samsun il sınırlarında bulunan meteoroloji istasyonlarına ait aylık toplam yağış ve sıcaklık değerleri

\begin{tabular}{|c|c|c|c|c|c|c|c|c|c|c|c|c|}
\hline \multirow[b]{3}{*}{$r$} & \multicolumn{12}{|c|}{ İstasyonlar } \\
\hline & \multicolumn{2}{|c|}{ Atakum } & \multicolumn{2}{|c|}{ Bafra } & \multicolumn{2}{|c|}{ Çarşamba } & \multicolumn{2}{|c|}{ Havza } & \multicolumn{2}{|c|}{ Lâdik } & \multicolumn{2}{|c|}{ Vezirköprü } \\
\hline & Yağ1ş & Sicaklik & Yağ1ş & Sicaklık & Yağ1ş & Sicaklık & Yağgiş & S1cakl1k & Yağış & Sicaklik & Yağ1ş & Sicaklik \\
\hline Ocak & 64.9 & 7.1 & 78.2 & 5.8 & 102.2 & 6.4 & 38.0 & 0.9 & 54.5 & 0.7 & 36.5 & 2.1 \\
\hline Şubat & 53.3 & 7.1 & 56.2 & 6.2 & 77.0 & 7.0 & 33.4 & 1.4 & 42.9 & 1.4 & 31.7 & 3.4 \\
\hline Mart & 61.5 & 8.1 & 56.5 & 7.5 & 76.2 & 8.3 & 31.3 & 50 & 47.5 & 4.1 & 37.3 & 7.5 \\
\hline Nisan & 58.7 & 11.4 & 52.3 & 11.1 & 81.4 & 12.2 & 50.6 & 10.1 & 62.2 & 8.9 & 56.7 & 12.2 \\
\hline Mayıs & 51.5 & 15.7 & 42.8 & 15.5 & 66.9 & 16.0 & 62.6 & 13.4 & 74.2 & 12.5 & 72.0 & 16.0 \\
\hline Haziran & 48.1 & 20.4 & 41.6 & 20.2 & 53.6 & 21.8 & 65.6 & 17.0 & 55.5 & 15.6 & 65.8 & 19.7 \\
\hline Temmuz & 33.1 & 23.3 & 27.6 & 22.9 & 59.6 & 23.3 & 37.0 & 19.1 & 25.8 & 17.7 & 30.5 & 22.1 \\
\hline Ağustos & 40.8 & 23.6 & 41.1 & 22.8 & 66.6 & 23.0 & 8.9 & 19.4 & 17.7 & 17.6 & 22.1 & 22.5 \\
\hline Eylül & 51.5 & 20.1 & 54.2 & 19.3 & 76.4 & 19.5 & 22 & 15.8 & 28.9 & 14.4 & 23.2 & 18.9 \\
\hline Ekim & 82.4 & 16.1 & 87.8 & 15.2 & 115.8 & 15.7 & 50.9 & 12.2 & 68.2 & 10.7 & 52.0 & 13.8 \\
\hline Kasım & 82.7 & 12.4 & 85.5 & 11.4 & 121.2 & 11.9 & 55.1 & 6.0 & 66.5 & 6.2 & 46.2 & 7.6 \\
\hline Aralık & 81.5 & 9.3 & 93.7 & 7.9 & 126.2 & 8.8 & 57.1 & 2.5 & 58.1 & 2.6 & 46.2 & 3.9 \\
\hline Y1ll1k & 710.0 & 14.6 & 717.5 & 13.8 & 1023.1 & 14.4 & 512.5 & 10.2 & 602.0 & 9.4 & 520.2 & 12.5 \\
\hline
\end{tabular}

\subsection{Yöntem}

Samsun ili toprak nem ve sicaklık rejimlerinin belirlenmesinde jNSM 1.6.0-Java Newhall Simülasyon Modeli (Van Wambeke ve ark., 1986, 1992; Newhall ve Berdanier, 1996; Van Wambeke, 2000), toprakların nem ve sicaklık rejimleri sınıflarının belirlenmesinde Toprak Sinıflaması (Anonymous, 1999) kullanılmıştır. Bölgenin iklim sınıflarının belirlenmesinde ise Erinç (1965) ve Thornthwaite (1948) yöntemleri kullanılmıştır.

\section{Bulgular ve Tartışma}

\subsection{Erinç ve Thornthwaite göre ilçelere ait iklim sinıfları}

Toprak oluşumunu etkileyen iklim faktörünün temel değişkenleri; yağış, sıcaklık, rüzgâr ve nem olup, bunlardan en etkilisi yağış ve sicaklıktır. Bu iki faktör kimyasal, fiziksel ve biyolojik süreçlerin şiddetlerini ve düzeylerini etkiler (Brady ve Weil, 2000). Yağış ve sıcaklık hem kayaların ayrışmasında hem de toprak profilinin özellik kazanmasında son derece etkilidir. Ayrıca bu iki faktör, toprak çözeltisine enerji ve nem sağlayarak toprak oluşumunu hızlandırır (Dinç ve ark., 1987). Samsun ili sahip olduğu farklı coğrafi ve iklim özellikleri ile tek bir iklim sınıfı içerisinde yer almamaktadır. Erinç (1965) iklim sınıflamasına göre Samsun ilinin doğu kısımları nemli sınıfı içerisinde yer alırken orta ve batı kesimler yarı nemli sınıfa girmektedir. Yapılan hesaplamaya göre Thornthwaite (1948) iklim siniflaması dikkate alındığında, Atakum iklimi $C 2, B^{\prime} 2, s, b$ '4 ile ifade edilen yarı nemli 2 . dereceden mezotermal, yazın orta derecede su noksan1, deniz etkisine yakın bir iklime sahiptir. Bafra ise $C 2, B^{\prime} 2, s, b$ ' 4 ile ifade edilen; yarı nemli, 2. dereceden mezotermal, yazın orta derecede su noksanı, deniz etkisine yakın bir iklime sahiptir. Çarşamba ilçesinin iklimi $B 1, B^{\prime} 2, s, b^{\prime} 4$ ile ifade edilen; nemli, 2. dereceden mezotermal, yazın orta derecede su noksanı, deniz etkisine yakın bir iklime sahiptir. Havza iklimi $C 2, B^{\prime} 1, s, b^{\prime} 4$ ile ifade edilen; yar1 nemli, 1. dereceden mezotermal, yazın orta derecede su noksanı, deniz etkisine yakın bir iklime sahiptir. Lâdik ilçesinin iklimi $C 2, B$ ' $1, s, b$ '4 ile ifade edilen; yarı nemli, 1. dereceden mezotermal, yazın orta derecede su noksanı, deniz etkisine yakın bir iklime sahiptir. Vezirköprü ilçesinin ise $C 1, B^{\prime} 2, d, b^{\prime} 4$ ile ifade edilen; kurak-yarı nemli, 2. dereceden mezotermal, su fazlası yok veya çok az, deniz etkisine yakın bir iklime sahiptir.

\subsection{Newhall modeline göre ilçelere ait toprak sıcaklık değişimi}

Samsun ili içerisinde yer alan ve uzun yıllar düzenli sıcaklık verileri içeren altı ilçe değerlerine göre Newhall modeli kullanılarak toprak sicaklık rejimleri belirlenmiştir. Buna göre, Atakum Meteoroloji İstasyonu'nun uzun y1llar ölçümleri göz önüne aldığında, yıllık ortalama sıcaklığı 14.6 ${ }^{\circ} \mathrm{C}$ olduğu görülmektedir. Toprak kontrol kesiti (50 cm toprak derinliği) sicaklığı aylık ortalama sıcaklıktan hesaplanmış olup, toprak sıcaklığ 5 ${ }^{\circ} \mathrm{C}$ 'nin altına düşmemektedir. Ocak ayının 18 'i ile Mart ayının 27 'si arasında $5{ }^{\circ} \mathrm{C}$ ile $8{ }^{\circ} \mathrm{C}$ derece arasında seyreden toprak sicaklığ 1 , Mart'ın $27^{\prime}$ 'sinden sonra $8{ }^{\circ} \mathrm{C}$ 'nin üzerine çıkmaktadır (Şekil 4). Model sonucuna göre toprak sicaklık rejimi Mesic olarak belirlenmiştir.

Bafra Meteoroloji İstasyonu'nun uzun yillar meteorolojik ölçümlere göre ise yıllık ortalama sıcaklığı Atakum ilçesine yakın olup, $13.8^{\circ} \mathrm{C}$ 'dir. Burada da toprak sıcaklığ $5{ }^{\circ} C^{\prime}$ nin altına düşmemektedir. Özellikle Ocak ayının birinci günü ile Nisan ayının 3 'ü arasında $5{ }^{\circ} \mathrm{C}$ ila $8{ }^{\circ} \mathrm{C}$ derece arasında seyreden toprak sicaklığı, 04 Nisan tarihinden sonra $8{ }^{\circ} \mathrm{C}$ 'nin üzerine çıkmaktadır 
(Şekil 5). Model sonucuna göre ilçenin toprak sıcaklık rejimi Mesic olarak belirlenmiştir.

Çarşamba Meteoroloji İstasyonu'nun uzun yıllar meteorolojik ölçümlere değerlerine göre, yıllık ortalama sicaklığı $14.4 \quad{ }^{\circ} \mathrm{C}$ olarak belirlenmiştir. Thornthwaite metoduna göre hesaplanan yıllık toplam evapotransprasyon miktarı ise $771.82 \mathrm{~mm}$ olarak bulunmuştur. Toprak sıcaklığ 11 Ocak-22 Mart tarihleri arasında $5{ }^{\circ} \mathrm{C}$ ila $8{ }^{\circ} \mathrm{C}$ derece arasinda seyrederken 23 Mart tarihinden sonra $8{ }^{\circ} \mathrm{C}$ 'nin üzerine çıkmaktadır (Şekil 6). Model sonucuna göre toprak sıcaklık rejimi Çarşamba ilçesinde de Mesic olarak belirlenmiştir.

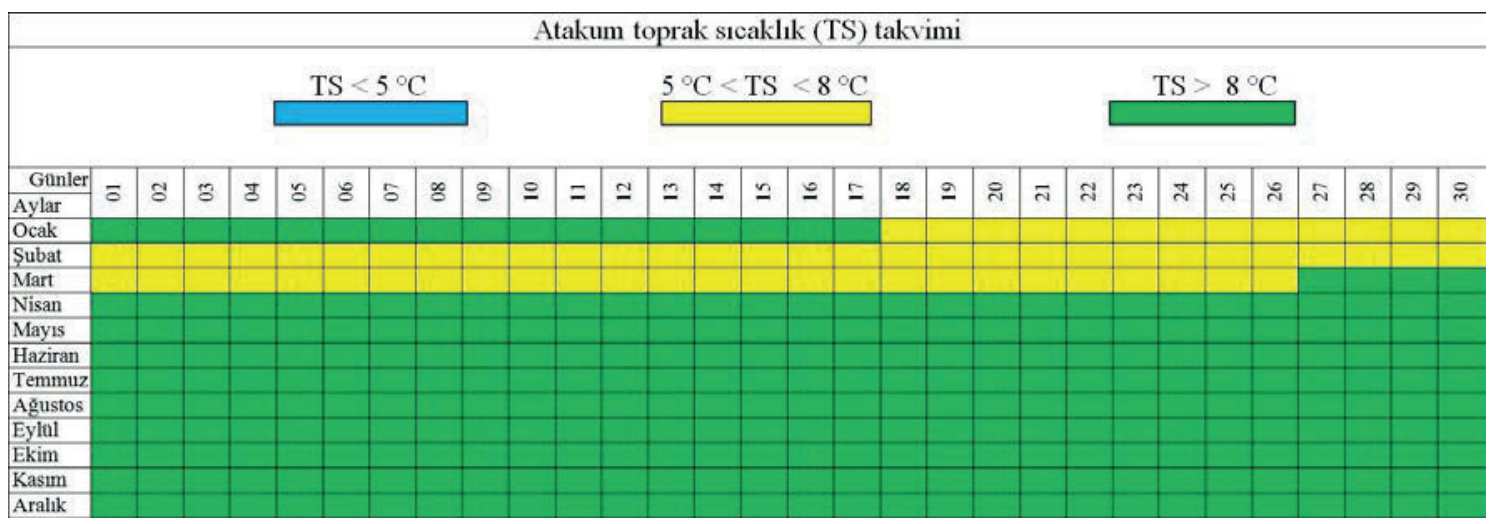

Şekil 4. Atakum ilçesi Newhall modeline göre toprak sıcaklık dă̆ılımı

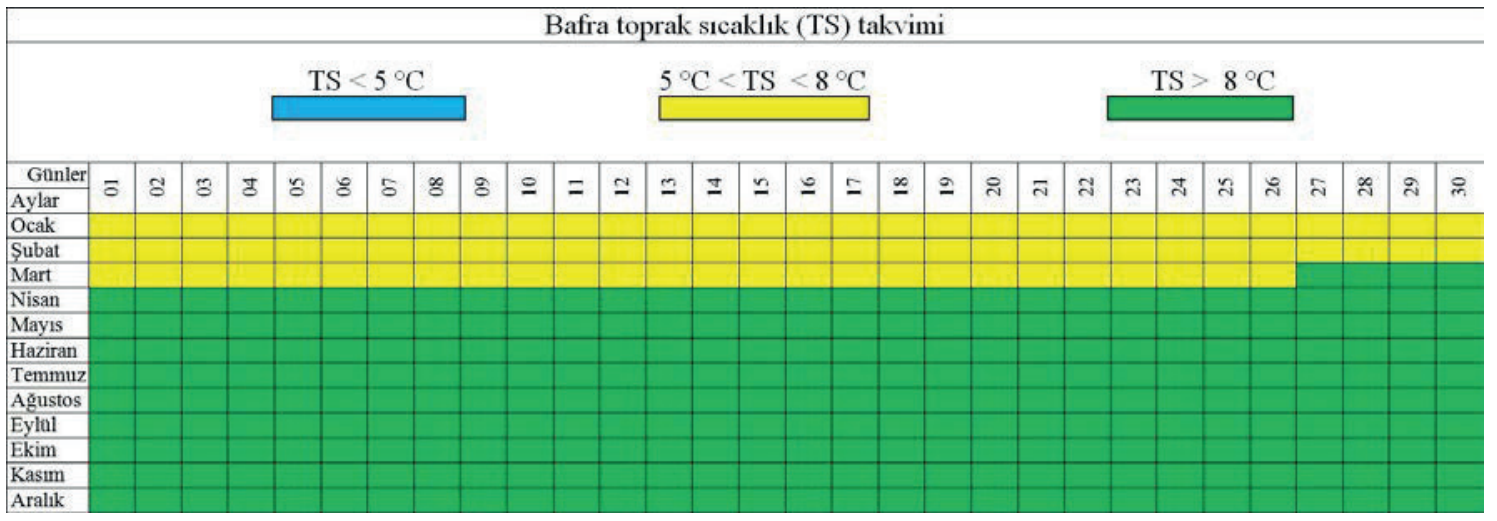

Şekil 5. Bafra ilçesi Newhall modeline göre toprak sıcaklık dağılımı

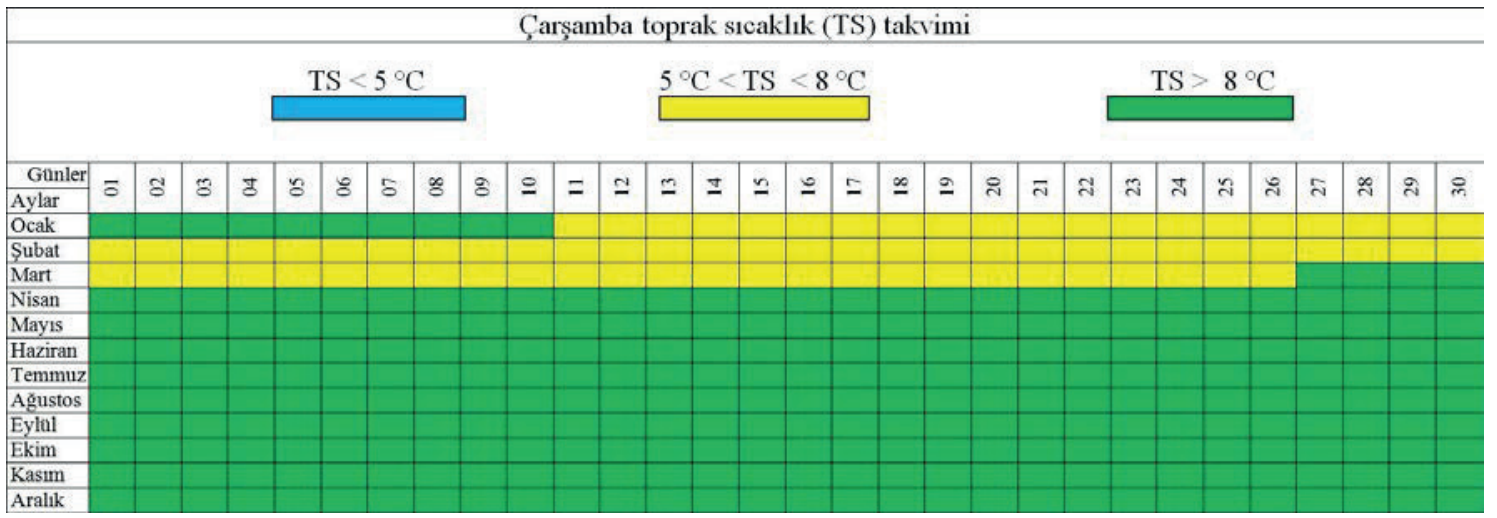

Şekil 6. Çarşamba ilçesi Newhall modeline göre toprak sıcaklık dağılımı

Havza Meteoroloji İstasyonu'nun uzun y1llar meteorolojik ölçümlere göre, yıllık ortalama sıcaklığı $\quad 10.3 \quad{ }^{\circ} \mathrm{C} \quad$ olduğu görülmektedir. Thornthwaite metoduna göre hesaplanan y1llı 
toplam evapotransprasyon miktarı ise 641.52 mm'dir. Havza İlçesindeki toprak sicaklığı 05 Aralık ile 05 Nisan tarihleri arasında $5{ }^{\circ} \mathrm{C}$ 'nin altına düşmektedir. Nisan ayının 6 ile 16 tarihleri ve 22 Kasım ile 4 Aralık tarihleri arasında $5{ }^{\circ} \mathrm{C}$ ila $8{ }^{\circ} \mathrm{C}$ derece arasında seyreden toprak sıcaklığı, 17 Nisan ile 21 Kasım tarihleri arasında $8{ }^{\circ} \mathrm{C}$ 'nin üzerine çıkmaktadır (Şekil 7). Model sonucuna göre Havza ilçesinin toprak sicaklık rejimi Mesic olarak belirlenmiştir.

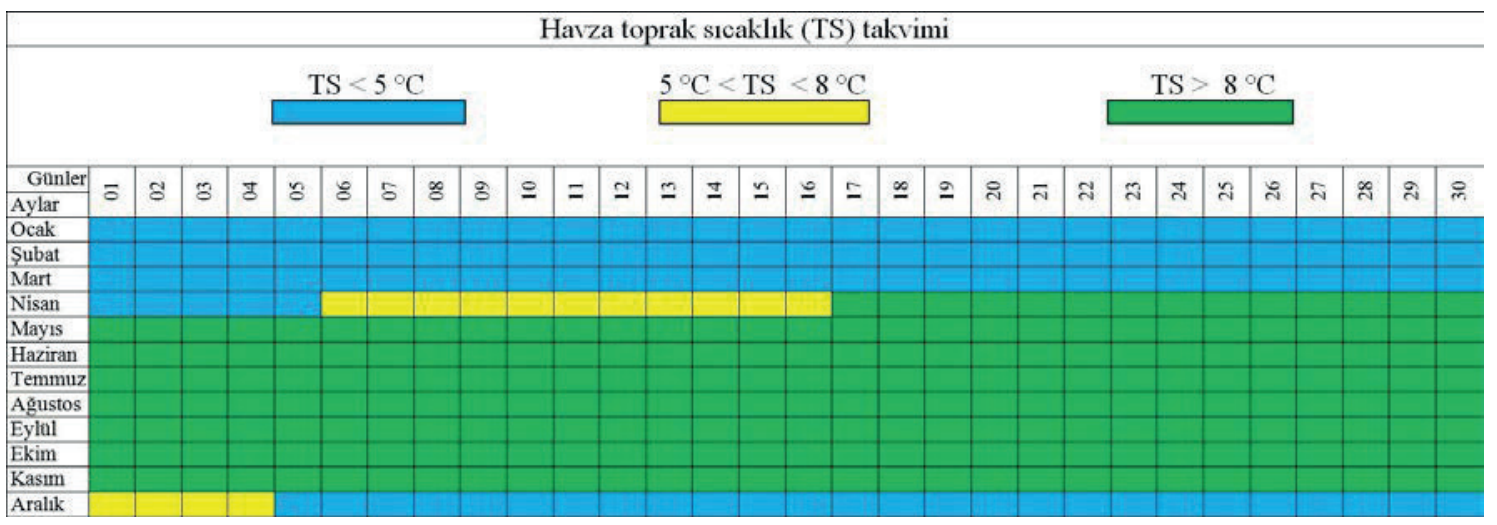

Şekil 7. Havza ilçesi Newhall modeline göre toprak sıcaklık dağılımı

Lâdik Meteoroloji İstasyonu'nun uzun yıllar meteorolojik ölçümlere verileri dikkate alındığında, yıllık ortalama sıcaklığı tüm ilçeler içerisinde en düşük değere sahip olup, $9.4{ }^{\circ} \mathrm{C}$ olduğu görülmektedir. Thornthwaite metoduna göre hesaplanan yıllık toplam evapotransprasyon miktarı ise $611.61 \mathrm{~mm}$ 'dir. İlçenin toprak sicaklığı 06 Aralık ile 10 Nisan tarihleri arasında diğer ilçelerin aksine $5{ }^{\circ} \mathrm{C}$ 'nin altına düşmektedir. Ayrıca, Nisan'ın 11'i ile 23 Nisan tarihleri ve 18 Kasım ile 05 Aralık tarihleri arasında $5{ }^{\circ} \mathrm{C}$ ila $8{ }^{\circ} \mathrm{C}$ derece arasında seyreden toprak sicaklığı, 24 Nisan ile 17 Kasım arasında $8{ }^{\circ} \mathrm{C}$ 'nin üzerine çıkmakta olduğu belirlenmiştir (Şekil 8). Model sonucuna göre ilçenin toprak sicaklık rejimi Mesic olarak belirlenmiştir.

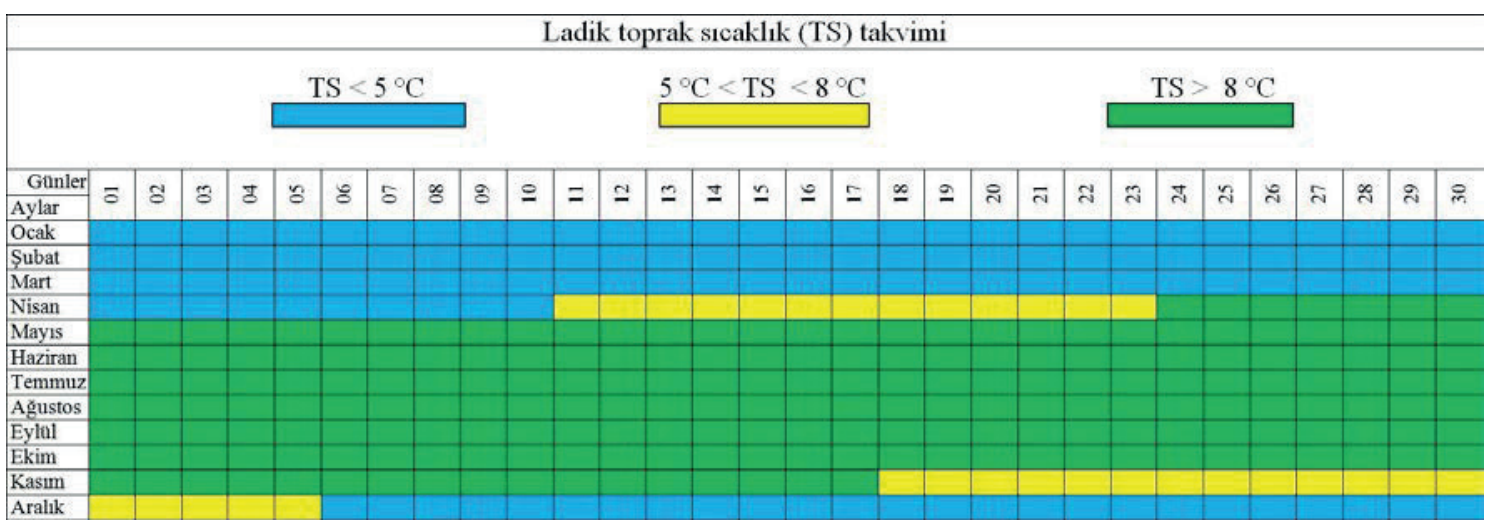

Şekil 8. Lâdik ilçesi Newhall modeline göre toprak sıcaklık dağılımı

Son olarak, Vezirköprü ilçesine ait meteoroloji istasyonunun uzun yıllar verilerine göre, y1llık ortalama sicaklığı $12.5{ }^{\circ} \mathrm{C}$ 'dir. Thornthwaite metoduna göre hesaplanan yillik toplam evapotransprasyon miktarı ise $724.5 \mathrm{~mm}$ 'dir. İlçenin toprak sıcaklığı 17 Aralık ile 16 Mart tarihleri arasında $5{ }^{\circ} \mathrm{C}$ 'nin altına düşmektedir. Ayrica toprak sicaklığı 17 Mart ile 02 Nisan tarihleri ve 29 Kasım ile 15 Aralık tarihleri arasında $5{ }^{\circ} \mathrm{C}$ ila $8{ }^{\circ} \mathrm{C}$ derece arasında belirlenmiştir. Buna karşıllk 03 Nisan ile 28 Kasım arasında toprak sıcaklığı $8{ }^{\circ} C^{\prime}$ nin üzerine çıkmaktadır (Şekil 9). Tüm diğer ilçelerde olduğu gibi Vezirköprü'de de model sonucuna göre toprak sicaklık rejimi Mesic olarak belirlenmiştir.

\subsection{Newhall modeline göre ilçelere ait toprak nem değişimi}

Samsun ili içerisinde yer alan ve uzun yillar düzenli yağış verileri içeren altı ilçe değerlerine göre Newhall modeli kullanılarak toprak nem rejimleri belirlenmiştir. Buna göre, Atakum 


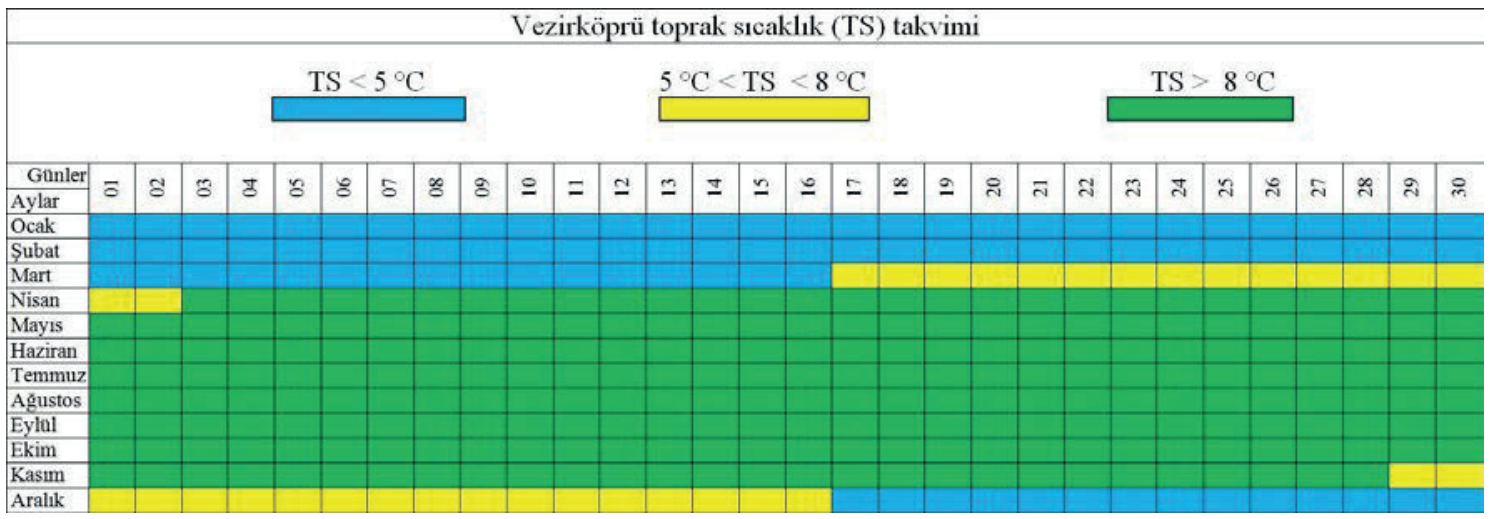

Şekil 9. Vezirköprü ilçesi Newhall modeline göre toprak sıcaklık dağılımı

Meteoroloji İstasyonu'nun uzun yıllar ölçümlere göre, y1llık toplam yağışı $710 \mathrm{~mm}$ olup, Thornthwaite metoduna göre hesaplanan y1llık toplam evapotransprasyon miktarı ise 774.25 mm'dir. Sonbahar aylarında yağışların başlaması ile birlikte toprak 16 Ekimde nemli duruma geçmiş ve bu durum haliyle kış ve bahar aylarında da devam ederek 26 Haziran tarihine kadar devam etmiş; 26 Haziran-15 Ekim tarihleri arasında toprak neminde farklılıklar meydana gelmiş olup, "kurunemli" ile "kuru" arasında değişmiştir. Atakum'da toprak 251 gün "nemli”, 42 gün "kuru-nemli”, 67 gün ise "kuru" kalmıştır. Toprakta su fazlalığı (akış) Eylül ayı ortalarında başlamış ve Nisan ayının ilk haftasına kadar devam etmiştir. Bu günlerden sonra evapotransprasyon ile harcanan su, yağış ile karşılanamamış ve bu su noksanlığı Temmuz ayında $108 \mathrm{~mm}$ ile en yüksek değere ulaşmıştır. Toprakta yıllık $64.25 \mathrm{~mm}$ su açığı bulunmaktadır (Şekil 10). İlçenin toprak nem rejimi sinıflaması Wet Tempustic olarak belirlenmiştir.

Bafra ilçesi meteoroloji istasyonunun 19632016 yılları arasındaki aylık ve yıllık ortalama verilerine göre; y1llık toplam yağışı $717.5 \mathrm{~mm}$ olup, Samsun'un doğu sahillerine göre bir miktar daha düşük yağış almaktadır. Sonbahar aylarında yağışların başlaması ile birlikte toprak 16 Ekimde nemli duruma geçmiş ve bu durum haliyle kış ve bahar aylarında da devam ederek Haziran ayı ortalarında birkaç gün "kuru-nemli" duruma geçse de "nemli" durumu 23 Hazirana kadar devam etmiştir. Toprak nemindeki farklılıklar 24 Haziran ile 15 Ekim tarihleri arasında görülmekte olup, "kuru-nemli" ile "kuru" arasında değişmiştir. Bafra'da toprak 245 gün "nemli", 54 gün "kurunemli", 61 gün ise "kuru" kalmış olduğu belirlenmiştir. Toprakta su fazlalığı (yüzey akış) Eylül ayı ortalarında başlamış ve Nisan ayının ilk haftasına kadar devam etmiştir. Bu günlerden sonra evapotransprasyon ile harcanan su, yağış ile karşılanamamış ve bu su noksanlığı Temmuz ayında $111.36 \mathrm{~mm}$ ile en yüksek değere ulaşmıştır.
Toprakta yıllık $34.81 \mathrm{~mm}$ su açığı bulunmaktadır (Şekil 11). İlçenin toprak nem sınıflaması Wet Tempustic olarak belirlenmiştir.

Çarşamba ilçesi Samsun il sınırları içerisinde yağış miktarı bakımından en yüksek değere sahip olup, meteoroloji istasyonunun uzun yıllar ölçüm verilerine göre yıllık toplam yağış1 $1023.1 \mathrm{~mm}$ 'dir. Sonbahar aylarında yağışların başlaması ile birlikte toprak Atakum ilçesinden bir ay önce yani 16 Eylülde nemli duruma geçmiş ve bu durum haliyle kış ve bahar aylarında da devam ederek 29 Haziran tarihine kadar devam etmiştir. Fakat 30 Haziran ile 15 Eylül tarihleri arasinda toprak neminde farklılıklar meydana gelmiş olup, "kuru-nemli" ile "kuru" arasında değişmiş olduğu belirlenmiştir. Çarşamba ilçesinde toprak 284 gün "nemli", 40 gün "kuru-nemli", 36 gün ise "kuru" kalmıştır. Toprakta su fazlalığı yani yüzey akışı Eylül ayının ilk haftasında başlamış ve Nisan ayının son haftasına kadar devam etmiştir. $\mathrm{Bu}$ günlerden sonra evapotransprasyon ile harcanan su, yağış ile karşılanamamış ve buda toprakta su noksanlığına neden oluştur. Özellikle toprakta su noksanlığ 1 Temmuz ayında $81.78 \mathrm{~mm}$ ile en yüksek değere ulaşmıştır. Buna karşın toprakta yıllık $251.8 \mathrm{~mm} \mathrm{su}$ fazlalığı bulunmaktadır (Şekil 12). Topraktaki bu su döngüsü, toprak nem rejimi sinıflamasına da yansiyarak toprak nem rejimi Dry Tempudic olarak belirlenmiştir.

Havza ilçesi, Samsun il sınırları içerisinde en düşük yağış miktarına sahip olan ilçe olup, meteoroloji istasyonunun uzun y1llar ölçüm verilerine göre yıllık toplam yağışı 512.5 mm'dir. Sonbahar aylarında yağışların başlaması ile birlikte Bafra ve Çarşamba ilçe sınırları içerisinde dağılım gösteren topraklara nazaran çok sonra, yani 16 Kasımda nemli duruma geçmiș ve bu durum haliyle kış ve bahar aylarında da devam ederek 22 Temmuz tarihine kadar devam etmiştir. Fakat 23 Temmuz ile 03 Ağustos tarihleri arasında toprak "kuru-nemli" olmasına karşın, Ağustosun üçünden Ekimin on 

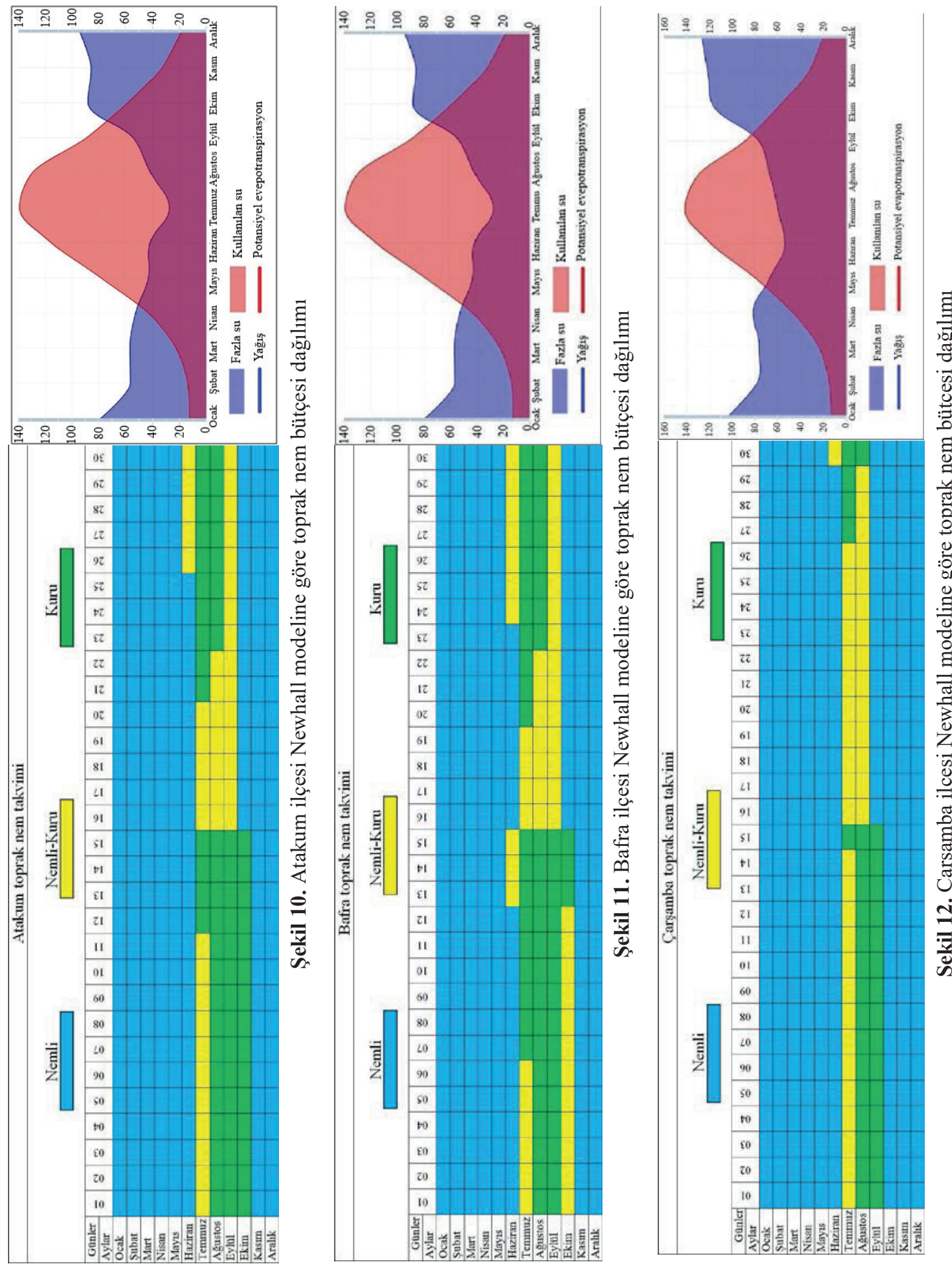
beşine kadar toprak "kuru" duruma geçmiştir. Toprak tekrar "kuru-nemli" duruma ise 16 Ekim ile 15 Kasım tarihleri arasında geçtiği belirlenmiştir. Havza ilçesinde topraklar 240 gün "nemli", 47 gün "kuru-nemli”, 73 gün ise "kuru” kalmıştır. Toprakta su fazlalığı Ekim ayı ilk günlerinde başlamış ve Nisan ayının ilk günlerine kadar devam etmiştir. Bu günlerden sonra gerek bitkiler gerekse de toprak yüzeyinden buharlaşan su, yani evapotransprasyon ile harcanan su, yağış ile karşılanamamış ve bu su noksanlığı Ağustos ayında $102.52 \mathrm{~mm}$ ile en yüksek değere ulaştığı belirlenmiştir. İlçe topraklarının yıllık $129.02 \mathrm{~mm}$ su noksanlığ $\breve{g}_{1}$ bulunmaktadır (Şekil 13). Su bütçesi hesaplamasına göre ilçe topraklarının toprak nem sinıflaması Typic Xeric olarak belirlenmiştir.

Lâdik ilçesi meteoroloji istasyonunun 19761999 yıllarına ait ölçüm verilerine dikkate alındığında, yıllık toplam yağışı miktarı Havza ilçesine göre bir miktar daha düşük olup, 602 mm'dir. Sonbahar aylarında yağışların başlaması ile birlikte toprak 16 Kasımda nemli duruma geçmiş ve bu durum kış ve bahar aylarından 20 Temmuz tarihine kadar devam etmiştir. Bu tarihten 29 Temmuza kadar toprak "kuru-nemli"dir. Temmuzun 30'undan 15 Ekim tarihine kadar toprak "kuru" duruma geçmesine karşın, 16 Ekim ile 15 Kasım arasında toprak tekrar "kuru-nemli" hale gelmiştir. Lâdik ilçesinde toprak, 236 gün "nemli", 57 gün "kuru-nemli”, 67 gün ise "kuru” kalmıştır. Toprakta su fazlalığı Havza ilçesinde olduğu gibi Eylül ayı ortalarında başlamış ve Nisan ayının sonuna kadar devam etmiştir. $\mathrm{Bu}$ tarihler arası özellikle eğimli ve yüzey örtüsü zayıf tarım arazileri, mera gibi alanlar erozyona maruz kalma riski ile karşı karşıyadırlar. Buna karşın çöküntü alanlar veya geçirimsiz katmanlara sahip olan topraklar drenaj bozukluğu nedeniyle topraklarda havalanma sorunu yaratabilmektedir. $\mathrm{Bu}$ günlerinden sonra toprak evapotransprasyon ile su kaybına uğramakta ve harcanan su yağış ile karşılanamamaktadır. Özellikle su noksanlığı Temmuz ve Ağustos ayında sırasıyla $85.52 \mathrm{~mm}$ ve $85.1 \mathrm{~mm}$ ile en yüksek değerlere ulaşmaktadır. Diğer ilçe topraklarında olduğu gibi su noksanlığ1 görülen aylarda da bitkilerin (özellikle dikili tarım alanlarında) su stresine girmemeleri açısından dikkate alınması gereken bir durumdur. Toprakta yıllık $9.6 \mathrm{~mm}$ su noksanlığı bulunmaktadır (Şekil 14).Toprak nem sinıflaması Typic Xeric olarak belirlenmiştir.

Vezirköprü ilçesi meteoroloji istasyonunun uzun yıllar ölçüm verilerine göre y1llık toplam yağışı miktarı 518.4 mm'dir. Sonbahar aylarında yağışların başlaması ile birlikte toprak 05 Aralıkta nemli duruma geçmiş ve bu durum haliyle kış ve bahar aylarında da devam ederek 03 Temmuz tarihine kadar devam etmiş; 04-22 Temmuz tarihleri arasında toprak "kuru-nemli" olmuştur. Bu tarihten sonra, yan1 23 Temmuz-15 Ekim tarihleri arasında toprak "kuru" duruma geçmiş ve 16 Ekim04 Aralık arasında toprak tekrar "kuru-nemli" olmuştur. Vezirköprü'de toprak 209 gün "nemli”, 68 gün "kuru-nemli", 83 gün ise "kuru” kalmıştır. Toprakların su fazlalığı Ekim ayı ilk günlerinde başlamış ve Nisan ayının ilk haftasına kadar devam etmiştir. Bu günlerden sonra evapotransprasyon ile harcanan su yağış ile karşılanamamış ve bu su noksanlığı Lâdik ilçesinde olduğu gibi Temmuz ve Ağustos ayında görülmesine karşın, toprakların su ihtiyaçları Lâdik ilçesinden daha fazla olup, sirasiyla $103.96 \mathrm{~mm}$ ve $106.97 \mathrm{~mm}$ olarak belirlenmiştir (Şekil 15). Genel anlamda topraklarda yaklaşı yıllık $206 \mathrm{~mm}$ su noksanlığ bulunmaktadır. İlçenin modele göre toprak nem sınıflaması Typic Xeric olarak belirlenmiştir.

\section{Sonuçlar}

Farklı coğrafi ve iklim özelliklerine sahip olan Samsun ili sınırları içerisinde yer alan toprakların sahil, orta ve iç kesimlerde yer alan altı meteorolojik istasyonlara ait uzun yillar aylık ortalama ve yıllık yağış ve sıcaklık verileri kullanılarak, toprakların toprak nem ve sicaklık değerleri Newhall modeli kullanılarak belirlenmiştir. Elde edilen sonuca göre, toprakların sicaklık rejimi il genelinde Mesic olarak belirlenirken, nem rejimleri oldukça farklılık gösterdiği belirlenmiştir. Yüksek kesimlerde (Havza, Vezirköprü ve Lâdik ilçeleri) toprak nem rejimi Typic Xeric iken, Samsun'un doğusu özellikle sahil kesimleri Dry Tempudic, buna karşın iç ve batı sahil kesimleri ise Wet Tempustic olarak belirlenmiştir. Ayrıca toprakların nem ve sıcaklık rejimlerinin belirlenmesi ile;

Toprak nem ve sicaklik rejimi toprak sınıflandırmasında kategorik düzeylerinin belirlenmesinde önemli bir girdi oluşturması,

Özellikle Türkiye'de su fazlalığının yaşandığ sonbahar ve kış aylarının yanı sıra, düzensiz yağışların meydana geldiği bölgelerinde yüzey akışa geçen fazla suyun, yamaç arazilerde erozyona neden olabilmektedir. $\mathrm{Bu}$ nedenle, bölgelerin su bütçesi hesaplamaları ile bu riskli dönemlerin belirlenmesinde,

Yine su fazlası dönemlerinde özellikle düz ve drenaj problemi yaşanan tarım arazilerinde göllenmelerin oluşması sonrası, havasız ortam yaratması nedeniyle ürün kayıplarına neden olmas1, 

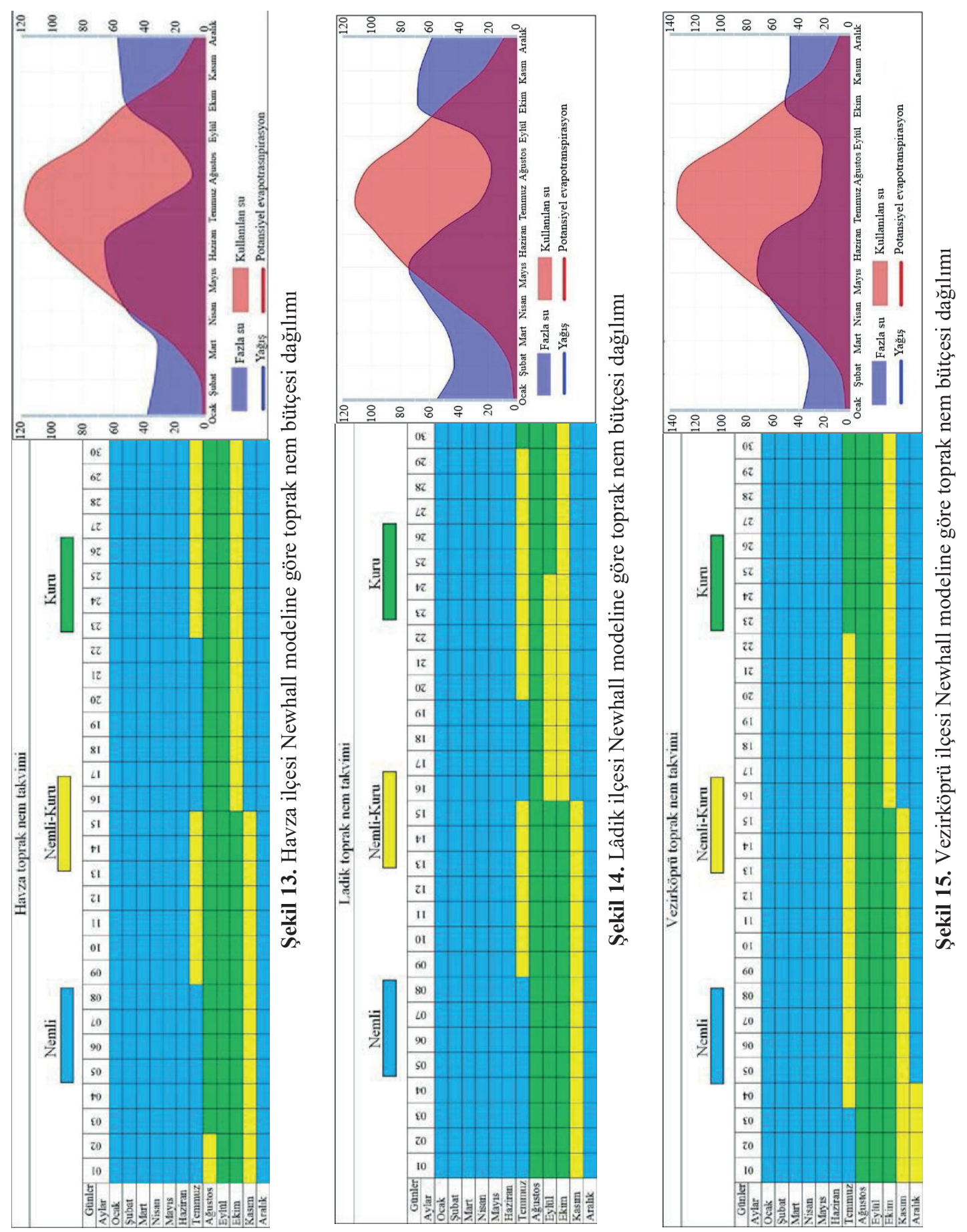
Toprakta su noksanlığı nedeniyle eksik suyun belirlenmesi, su ve kuraklık yönetimi ve planlamalarında önemli bir altlık oluşturması,

$>$ Toprak çeşitleri ile toprak nem ve sıcaklık bütçeleri arasındaki ilişkiye bağlı çölleşme modellerinin geliştirilmesinde, toprak su ve sicaklı rejimlerinin önemli rolleri bulunmaktadır.

Sonuç olarak, yapılan hesaplamalara göre Samsun ili sınırları içerisinde coğrafi koşulların değişikliğinden dolayı farklı klimatolojik koşullar ortaya çıkmaktadır. Bu da Samsun ili sınırları içerisinde özellikle farklı toprak nem rejimlerinin oluşmasına neden olduğu belirlenmiştir.

\section{Kaynaklar}

Anonim, 1980. Tarım Arazilerinde Erozyon ve Toprak Koruma. Köy İşleri ve Kooperatifler Bakanlığı, Toprak Su Genel Müdürlüğü, Yayın No: 43, Tokat.

Anonymous, 1999. Soil Survey Staff. A Basic of Soil Classification for Making and Interpreting Soil Survey. U.S.D.A Handbook No: 436, Washington D.C.

Akalan, İ., 1969. Türkiye'nin Bazı Tipik Büyük Toprak Gruplarının Kil ve Mil Mineralojisi Üzerinde Bir Araştırma. Ankara Üniversitesi Ziraat Fakültesi Yayınları, Ankara Üniversitesi Basımevi, Ankara.

Brady, N.C., Weil, R.R., 2000. Elements of the Nature and Properties of Soils. Prentice hall Upper Saddle River, NJ, USA.

Buol, S.W., Hole, F.D., McCracken, R.J., 1973. Soil Genesis and Classification. The Iowa State University Press, pp. 360.

Dengiz, O., Sarığlu, F.E., 2011. Samsun ilinin potansiyel tarım alanlarının genel dağılımları ve toprak etüd ve haritalama çalışmalarının önemi. Anadolu Tarım Bilimleri Dergisi, 26(3): 241-253.

Dengiz, O., Ekberli, İ., 2017. Bazı vertisol alt grup topraklarının fizikokimyasal ve 1sisal özelliklerinin incelenmesi. Akademik Ziraat Dergisi, 6(1): 45-52.

Dinç, U., Kapur, S., Özbek, H., Șenol, S., 1987. Toprak Genesisi ve Sınıflandırması. Çukurova Üniversitesi Basımevi, Çukurova Üniversitesi Yayınları Ders Kitab1, No 7.1.3.

Ekberli, İ., Dengiz, O., 2016. Bazı inceptisol ve entisol alt grup topraklarının fiziko-kimyasal özellikleriyle 1sısal yayınım katsayısı arasındaki regresyon ilişkilerin belirlenmesi. Toprak Su Dergisi, 5(2): 110.

Ekberli, İ., Gülser, C., 2014. Estimation of soil temperature by heat conductivity equation. Başkurt Devler Ziraat Üniversitesi Bülteni, 2(3): 12-15.

Ekberli, İ., Gülser, C., Özdemir, N., 2015. Toprakta 1S1 iletkenliğine etki yapan isısal parametrelerin teorik incelemesi. Anadolu Tartm Bilimleri Dergisi, 30(3): 300-306.

Ekberli, İ., Sarılar, Y., 2015. Toprak sıcaklığı ve 1sısal yayınımın belirlenmesi. Anadolu Tarm Bilimleri Dergisi, 30(1): 74-85.

Erinç, S., 1965. Yağıș Muessiriyeti Üzerine Bir Deneme ve Yeni Bir İndis. İstanbul Üniversitesi, Coğrafya Enstitüsü.

Erşahin, S., 2001. Toprak Amenajmanı. Gaziosmanpaşa Üniversitesi, Ziraat Fakültesi Ders Notları Serisi, Tokat.

Joffe, J.S., 1949. Pedology. New Brunswick.

Gao, Z., Bian, L., Hu, Y., Wan, L., Fan, J., 2007. Determination of soil temperature in an arid region. Journal of Arid Environments, 71(2): 57-168.

Newhall, F., Berdanier, C.R., 1996. Calculation of Soil Moisture Regimes from the Climatic Record. Soil Survey Investigations Report No. 46, National Soil Survey Center, Natural Resources Conservation Service, Lincoln, NE.

Özgener, Ö., Özgener, L., Tester, J.W., 2013. A practical approach to predict soil temperature variations for geothermal (ground) heat exchangers applications. International Journal of Heat and Mass Transfer, 62: 473-480.

Simonson, R.W., 1959. Outline of a generalized theory of soil genesis. Soil Science Society of America Journal, 23: 52-156.

Tanju, Ö., 1996. Toprak Genesisi ve Sinıflandırma. Ankara Üniversitesi Ziraat Fakültesi, Yayın No: 1472, Ders Kitab1 No: 437, Ankara.

Thornthwaite, C.W., 1948. An approach towards a rational classification of climate. Geographical Review, 38(1): 55-94.

Trombotto, D., Borzotta, E., 2009. Indicators of present global warming through changes in active layerthickness, estimation of thermal diffusivity and geomorphological observations in the Morenas Coloradas rock glacier, Central Andes of Mendoza, Argentina. Cold Regions Science and Technology, 55: 321-330.

Van Wambeke, A.R., 2000. The Newhall Simulation Model for Estimating Soil Moisture \& Temperature Regimes. Department of Crop and Soil Sciences, U.S. Departmanet of Agriculture, Ithaca, N.Y. Washington, DC.

Van Wambeke, A., Hastings, P., Tolomeo, M., 1986. Newhall Simulation Model: A BASIC Program for The IBM PC. Department of Agronomy, Cornell University. Diskette and Booklet. Ithaca, NY. Washington, DC.

Van Wambeke, A., Hastings, P., Tolomeo, M., 1992. Newhall Simulation Model-A BASIC Program for the IBM PC (DOS 2.0orlater). Cornell University, Department of Agronomy, Ithaca, NY. Washington, DC. 